\title{
Lignin Degradation by Fusarium solani f. sp. glycines
}

\author{
V. V. Lozovaya, A. V. Lygin, O. V. Zernova, S. Li, and J. M. Widholm, Department of Crop Sciences, and \\ G. L. Hartman, United States Department of Agriculture-Agricultural Research Service and Department of Crop \\ Sciences, National Soybean Research Center, University of Illinois, Urbana 61801
}

\begin{abstract}
Lozovaya, V. V., Lygin, A. V., Zernova, O. V., Li, S., Widholm, J. M., and Hartman, G. L. 2006. Lignin degradation by Fusarium solani f. sp. glycines. Plant Dis. 90:77-82.

Sudden death syndrome (SDS), caused by the soilborne fungal pathogen Fusarium solani f. sp. glycines, is one of the most important diseases of soybean. Lignin degradation may play a role in the infection, colonization, and survival of the fungus in root tissue. Lignin degradation by $F$. solani f. sp. glycines was shown by the catalyzed release of ${ }^{14} \mathrm{CO}_{2}$ from purified ${ }^{14} \mathrm{C}$-labeled Klason lignin, the degradation of polymeric aromatic dyes in culture (a method commonly used to test the ligninolytic capacity of microorganisms), and the production of laccase and lignin peroxidase (the major fungal lignin degrading enzymes). The laccase and lignin peroxidase activities and the amount of decolorization of aromatic polymeric dyes (Poly R-478 and Remazol Brilliant Blue R) by F. solani f. sp. glycines were intermediate or greater than that found with two known lignin-degrading fungi, Polyporus tulipifera and Schizophyllum commune. Studies of lignin synthesis from $\left[{ }^{14} \mathrm{C}\right]$ phenylalanine with soybean hairy root cultures showed that $F$. solani f. sp. glycines treatment stimulated lignin synthesis in $2 \mathrm{~h}$, and by $24 \mathrm{~h}$, some lignin degradation had occurred. These results indicate that $F$. solani $\mathrm{f}$. sp. glycines was capable of degrading lignin which may be important in infection, colonization, and survival of the fungus.
\end{abstract}

Levels of resistance in crops to fungi could be increased by understanding and then genetically manipulating metabolic events that lead to production of antimicrobial compounds that are toxic to pathogens or that can strengthen the barriers of plant cells to pathogen entry (6). Plant cell wall phenolics can play an important protective role against pathogen invasion. By comparing transcript abundance of two soybean (Glycine max L. Merr.) genotypes with different sudden death syndrome (SDS) foliar resistance, it was found that the phenylpropanoid pathway products are involved in soybean plant defense against Fusarium solani f. sp. glycines (18), and the accumulation of the phenylpropanoid phytoalexin glyceollin in soybean root tissues may help provide resistance to $F$. solani $\mathrm{f}$. sp. glycines (26). It is known that hydroxycinnamic acid derivatives, esterified to cell wall constitu-

Corresponding author: G. L. Hartman

E-mail: ghartman@uiuc.edu

Mention of a trademark, proprietary product, or vendor does not constitute a guarantee or warranty of the product by the United States Department of Agriculture or the University of Illinois and does not imply its approval to the exclusion of other products or vendors that may also be suitable.

Accepted for publication 16 August 2005.

\section{DOI: 10.1094/PD-90-0077}

This article is in the public domain and not copyrightable. It may be freely reprinted with customary crediting of the source. The American Phytopathological Society, 2006. ents, can protect the complex carbohydrates from hydrolysis by fungal enzymes (11). The important cell wall complex aromatic polymer lignin (formed by oxidative polymerization of p-coumaryl, coniferyl, and sinapyl alcohols) can provide a barrier to fungal entry and to the diffusion of fungal toxins and enzymes into plant cells $(1,10,42)$. Some pathogens are known to be able to degrade lignin $(2,3,9,24)$ by laccase (p-diphenol:oxygen oxidoreductase; EC 1.10.3.2) and lignin peroxidase (EC 1.11.1.14) that are extracellular ligninolytic enzymes produced in some fungi. Laccase is a coppercontaining enzyme that catalyzes the oxidation of phenolic substrates by coupling it to the reduction of oxygen to water (22). Fungal laccases display a wide substrate range and are known to catalyze the polymerization, depolymerization, and methylation or demethylation of phenolic compounds (32). Lignin peroxidase oxidizes a variety of phenolic compounds and nonphenolic aromatic compounds. These peroxidases remove an electron from phenolic hydroxyl, aromatic amino groups, or other aromatic side chains to form free radicals. Ligninolytic activity has not been determined for most plant pathogens, including $F$. solani $\mathrm{f}$. sp. glycines.

SDS of soybean is a mid- to late-season disease with distinctive foliar symptoms, including interveinal chlorosis and necrosis (16). SDS first was observed in Arkansas in 1971 and currently occurs in most of the soybean-producing states, with yield loss in severely affected areas ranging from slight to nearly $100 \%$ (16).
The fungus enters the root, causing root necrosis, and produces a toxin or toxins that cause interveinal chlorosis and necrosis in the leaves (14). Some soybean genotypes have been identified that exhibit partial resistance based on decreased foliar symptoms $(15,17)$, even though they exhibit root damage caused by $F$. solani f. sp. glycines infection, which may reduce plant health. Other soybean lines have been identified as having some root resistance (18). Soybean resistance to $F$. solani f. sp. glycines may be due to metabolic events above- or belowground. There is a lack of information related to the biochemical activities that occur during infection and colonization of roots.

Due to the difficulty of working with roots and root pathogens in soil, hairy root cultures may be useful to study soybean plant root-pathogen interactions as a model system for root biochemistry and disease resistance tests. In earlier studies, it was reported that soybean hairy roots are similar to those of plant roots in terms of the same soluble and cell-wall-bound phenolics, and the changes induced by $F$. solani f. sp. glycines infection $(25,27)$. The objectives of our experiments were to determine whether $F$. solani f. sp. glycines can degrade lignin and whether infection affects lignin synthesis and accumulation in cell walls of soybean hairy roots.

\section{MATERIALS AND METHODS}

Fungal isolates. $F$. solani $\mathrm{f}$. sp. glycines isolate Mont-1 was obtained from the Soybean Pathogen Culture Collection Center, University of Illinois. Isolates of Polyporus tulipifera and Schizophyllum commune, known wood-degrading fungi, were obtained courtesy of Dr. Lisa Vaillancourt, University of Kentucky. Cultures were grown on potato dextrose agar (PDA; Difco Laboratories, Detroit) at $23^{\circ} \mathrm{C}$ in the dark for 5 days before being transferred for specific assays.

Degradation of ${ }^{14} \mathrm{C}$-labeled Klason lignin. ${ }^{14} \mathrm{C}$-labeled Klason lignin was obtained from cell walls of hairy roots (cv. Spencer) according to a previously described procedure (8). Then, $8 \mu \mathrm{Ci}$ of $\left[{ }^{14} \mathrm{C}(\mathrm{U})\right]$-phenylalanine (Phe) (NEN Life Science Products, Inc., Boston) in buffer (50 mM 2-( $N$-morpholino)ethanesulfonic acid [MES], $\mathrm{pH}$ 5.21) was fed for $24 \mathrm{~h}$ at $28^{\circ} \mathrm{C}$ to hairy roots in order to label the cell-wall-bound phenolics. Klason lignin was obtained as the insoluble residue after cell wall treatment with $72 \%$ sulfuric acid 
(vol/vol) for $2 \mathrm{~h}$ at $20^{\circ} \mathrm{C}$ and boiling in $3 \%$ sulfuric acid for $4 \mathrm{~h}$ to eliminate cell wall protein and carbohydrates. Residue obtained after centrifugation $(10 \mathrm{~min}$ at $11,000 \times g$ ) was washed with distilled water until the $\mathrm{pH}$ was neutral and dried at $60^{\circ} \mathrm{C}$. After drying, the lignin was crushed with a mortal and pestle to a fine powder. Lignin powder $(50 \mathrm{mg})$ with a specific activity of $400 \mathrm{cpm} / \mathrm{mg}$ was spread evenly as a thin layer over the surface of solid water agar (1\% Bacto agar, Difco Laboratories) medium in petri dishes (60 by 15 $\mathrm{mm}$ ). Three 5-mm-diameter plugs of $F$. solani $\mathrm{f}$. sp. glycines mycelium grown on PDA were placed on labeled lignin. Three uncovered dishes, two with lignin and fungus and one with a $20 \%$ solution of $\mathrm{KOH}$ (to trap the ${ }^{14} \mathrm{CO}_{2}$ produced during lignin degradation by fungus), were placed into large petri dishes ( 150 by $15 \mathrm{~mm}$ ) and sealed using parafilm. Samples with radioactive lignin but without fungus and fungus without lignin were used as controls. Treatments were arranged in a completely randomized design and the experiment was conducted three times. The ${ }^{14} \mathrm{CO}_{2}$ evolved as a result of $F$. solani f. sp. glycines lignin degradation during 4 weeks was trapped by $\mathrm{KOH}(20 \%)$ present in the container (Fig. 1 ), and the alkali was neutralized and its radioactivity was quantified with a Liquid Scintillation Analyzer Tri-Carb 1600 TR (Packard BioScience Co., Meriden, CT).

Decolorization of polymeric dyes. Protocols of assays used for screening of microbial ligninolytic activities were followed (30,32). The polymeric dyes Poly R-478 or Remazol Brilliant Blue R (Sigma-Aldrich, St. Louis) were added to Erlenmeyer flasks $(250 \mathrm{ml})$ containing 50 $\mathrm{ml}$ of a liquid hairy root culture medium known as MXB (Murashige-Skoog medium [31] basal salts, B5 [13] vitamins, and $2 \%$ sucrose $[\mathrm{pH} 5.7])$ as $1 \mathrm{ml}$ of a concentrated aqueous solution to give a

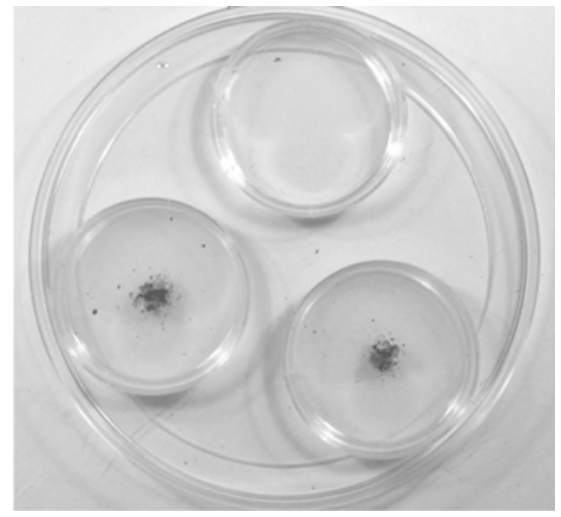

Fig. 1. Klason lignin degradation test: Fusarium solani f. sp. glycines as mycelial plugs was placed on a layer of Klason lignin in two petri dishes, while a third dish contained $20 \% \mathrm{KOH}$ in order to trap the ${ }^{14} \mathrm{CO}_{2}$ produced as a result of lignin degradation. The large petri dish was 15 $\mathrm{cm}$ in diameter and the small ones were $6 \mathrm{~cm}$ in diameter. final dye concentration of $0.02 \%$ (wt/vol). Three flasks each with Poly R-478 or Remazol Brilliant Blue $\mathrm{R}$ were amended with eight mycelial plugs of each of the three fungal species tested (18 flasks total) and incubated in a completely randomized design in the dark on a G-53 shaker (Brunswick Scientific Co. Inc., Edison, $\mathrm{NJ})$ at $50 \mathrm{rpm}$ for 21 days at $23^{\circ} \mathrm{C}$. The experiment was conducted twice. Sodium azide at a final concentration of $20 \mathrm{mM}$ was added to 18 additional flasks containing the same fungal cultures and dyes to prevent fungal growth. These flasks were used as the control flasks for the decolorization measurements. A $0.1-\mathrm{ml}$ sample of medium was removed periodically and diluted 10-fold in order to measure the decolorization of dyes by fungi over time. The absorbance ratios (A521/A345 for Poly R-478 and A591/A500 for Remazol Brilliant Blue R) were measured using a DU 640 spectrophotometer (Beckman Instruments Inc., Fullerton, CA). A decrease in the absorbance ratios indicated decolorization of the dyes $(33,35)$.

Laccase and lignin peroxidase activity. Activities of extracellular ligninolytic enzymes were measured in $F$. solani $\mathrm{f}$. sp. glycines in comparison with the two known lignin-degrading fungi when grown both in potato dextrose broth (PDB; Sigma-Aldrich) fungal culture medium and on hairy root culture medium. Three 4mm-diameter mycelial plugs cut from the margin of purified cultures of the three fungal species grown on PDA were transferred separately to flasks $(250 \mathrm{ml})$ with $100 \mathrm{ml}$ of PDB and to MXB liquid medium and incubated at $23^{\circ} \mathrm{C}$ in the dark. There were three replications for each of the three fungal species in each of the two different media arranged in a completely randomized design. The experiment was conducted twice. Extracellular activities of lignin-degrading enzymes, laccase, and lignin peroxidase, were measured 7, 14, and 21 days after inoculation.

To measure extracellular activities of lignin-degrading enzymes, aliquots of fungal culture medium were taken after 7 , 14 , and 21 days of fungal growth, purified from fungal tissue by filtration through a $0.2-\mu \mathrm{m}$ membrane, and used for assays. Laccase activity was determined as previously described (30) by measuring an increase in the absorbance at $436 \mathrm{~nm}$ with 5 $\mathrm{mM}$ 2,2'-azino-bis-(3-ethylbenzthiazoline6-sulfonic acid) diammonium salt as substrate in $100 \mathrm{mM}$ sodium acetate buffer, $\mathrm{pH} 4.5\left(\varepsilon_{436}=29.30 \mathrm{mM}^{-1} \mathrm{~cm}^{-1}\right)$ at $25^{\circ} \mathrm{C}$. Laccase activity was expressed as microkatals (micromoles of substrate converted per minute) per liter of extracellular culture fluid.

Lignin peroxidase activity was determined as oxidation of veratryl alcohol to veratraldehyde $\left(\varepsilon_{310}=9.3 \mathrm{mM}^{-1} \mathrm{~cm}^{-1}\right)$ in the presence of hydrogen peroxide. The increase of absorbance was measured at
$310 \mathrm{~nm}$ at $25^{\circ} \mathrm{C}$ after 10 to $20 \mathrm{~min}$ of reaction as previously described (29). The reaction consisted of $0.5 \mathrm{ml}$ of culture filtrate, $0.05 \mathrm{ml}$ of $10 \mathrm{mM} \mathrm{H}_{2} \mathrm{O}_{2}, 0.375 \mathrm{ml}$ of $0.33 \mathrm{M}$ sodium tartrate $(\mathrm{pH} 3.0), 0.45$ $\mathrm{ml}$ of distilled water, and $0.125 \mathrm{ml}$ of 4 $\mathrm{mM}$ veratrylic alcohol. Lignin peroxidase activity was expressed as microkatals per liter of extracellular culture fluid.

Induction of hairy roots, inoculation with $F$. solani f. sp. glycines, and determination of lignin content. Two soybean entries, partially resistant line PI567.374 and susceptible cv. Spencer, that differed in SDS foliar symptom severities were selected $(15,17)$. Hairy roots were induced using methods previously described (37) that were improved and modified by inoculating only the excised cotyledons (5). Briefly, cotyledons from seedlings germinated under sterile conditions were wounded and co-cultivated with Agrobacterium rhizogenes strain K599 (a gift from Dr. Stephen Farrand, University of Illinois, Urbana) for 4 days and then incubated on solid medium containing carbenicillin at $500 \mathrm{mg} \mathrm{liter}^{-1}$ to inhibit bacterial growth. Two weeks after root emergence from the wounded part of the explants, 2-cm-long root segments were removed and transferred to fresh medium to establish individual root clones. Transformed $A$. rhizogenes-free roots were obtained by three to four passages of 2 weeks each on the antibiotic medium at $24^{\circ} \mathrm{C}$ in the dark. Hairy roots were identified by their extensive branching and fast growth. Hairy roots were cultured on MXB medium solidified with Gelrite (Greif Bros. Corp., Sportswood, $\mathrm{NJ}$ ) at $3 \mathrm{~g} / \mathrm{liter}$.

Established hairy root cultures were treated with $0.5 \mathrm{ml}$ of $F$. solani f. sp. glycines macroconidial suspensions (sprayed at $10^{3}$ conidia/ml). Macroconidial suspensions were obtained by flooding $10 \mathrm{ml}$ of sterile distilled water on top of 2-week-old cultures grown on PDA. The concentration of the macroconidia suspension was determined using a hemacytometer (25).

The lignin content was determined by the Klason and thioglycolic acid methods. Klason lignin was obtained using a standard procedure as the insoluble residue after cell wall treatment with a mixture of acids as described above (6). Lignin also was assayed by derivatization with thioglycolic acid (1).

Three-week-old soybean root samples (400 $\mathrm{mg}$, fresh weight) were ground in liquid nitrogen in a mortar and pestle and extracted with five volumes of $80 \%$ methanol at $20^{\circ} \mathrm{C}$ with vigorous shaking (120 rpm; G 10, Brunswick Scientific Co.) for $12 \mathrm{~h}$. The pellet obtained after centrifugation at $5,000 \times g$ for $10 \mathrm{~min}$ was washed twice with chloroform:methanol (1:1, $\mathrm{vol} / \mathrm{vol}$ ) followed by $100 \%$ methanol, and the alcohol-insoluble residue was dried at $65^{\circ} \mathrm{C}$ and used for measurements of lignin content. The alcohol-insoluble residue (10 
$\mathrm{mg}$ ) was placed in a 1.5-ml Eppendorf screw-cap vial and treated with $1 \mathrm{ml}$ of 2 $\mathrm{M} \mathrm{HCl}$ and $0.2 \mathrm{ml}$ of thioglycolic acid for $4 \mathrm{~h}$ at $95^{\circ} \mathrm{C}$. After being cooled to room temperature, the mixture was centrifuged for $10 \mathrm{~min}$ at $12,000 \times g$ in a bench-top centrifuge. The supernatant was removed with a Pasteur pipette, and the remaining pellet was washed three times with distilled water. The pellet was suspended in 1 $\mathrm{ml}$ of $0.5 \mathrm{M} \mathrm{NaOH}$ and vigorously shaken overnight to extract the thioglycolic acid lignin. Following centrifugation as above, the supernatant was decanted into a 2-ml Eppendorf vial, and the pellet was washed with $0.5 \mathrm{ml}$ of $0.5 \mathrm{M} \mathrm{NaOH}$. The combined alkali extract was acidified with 0.3 $\mathrm{ml}$ of concentrated $\mathrm{HCl}$ and the lignin was allowed to precipitate at $4^{\circ} \mathrm{C}$ for $4 \mathrm{~h}$. The mixture was centrifuged as above, the supernatant was removed with a Pasteur pipette, and the brown pellets were dissolved in $1 \mathrm{ml}$ of $0.5 \mathrm{M} \mathrm{NaOH}$ and diluted to $10 \mathrm{ml}$ with $0.5 \mathrm{M} \mathrm{NaOH}$. A $1-\mathrm{ml}$ aliquot was used to measure the absorption at 280 $\mathrm{nm}$. A calibration curve was obtained using the hydrolytic, hydroxymethyl derivative of lignin (Aldrich Chemical Co., St. Louis) treated as described above. An aliquot of the sample was neutralized with $1 \mathrm{~N} \mathrm{HCl}$ and used to measure thioglycolic acid lignin radioactivity with a Liquid Scintillation Analyzer Tri-Carb 1600 TR (Packard BioScience Co.). The experiment was conducted twice.

Statistical analysis. Means and their standard errors were computed from data collected on the degradation of ${ }^{14} \mathrm{C}$-labeled Klason lignin. Data from all other experiments were subjected to analysis of variance (ANOVA) using JMP (version 5.1; SAS Institute Inc., Cary, NC). Experiment repeats (trials) and replications were considered random variables, whereas treatments were fixed. Mean separation was done by calculating the least significant difference at $P=0.05$ when treatment means were significantly different $(P<$ 0.05) in the ANOVA.

\section{RESULTS}

Degradation of ${ }^{14} \mathrm{C}$-labeled Klason lignin. In three experiments, the total $\mathrm{CO}_{2}$ radioactivity released by $F$. solani f. sp. glycines grown on radiolabeled Klason lignin as the sole substrate was 1,000 \pm $120,770 \pm 60$, and $830 \pm 90 \mathrm{cpm}$ (means with standard error), which was 2.5, 1.9, and $2.1 \%$ of the total lignin radioactivity present, respectively. Only background counts (20 to $25 \mathrm{cpm}$ ) were found in the controls without fungus or lignin.

Decolorization of polymeric dyes. There was a significant interaction between trials and treatments and the data were not combined within either dye experiment. For Poly R-478, only F. solani f. sp. glycines had significant degradation at each sampling time in trial one. In trial two, there was no significant degradation until 21 days after incubation. $P$. tulipifera caused the greatest degradation at 42 days. For Remazol Brilliant Blue R, decolorization occurred as early as 3 and 7 days in trial one and two, respectively, and was significantly less by $S$. commune than by $F$. solani f. sp. glycines and $P$. tulipifera after 14 days until the end of the experiment (Table 1).

Laccase and lignin peroxidase activity. Within each enzyme tested, there was not a significant trial-treatment interaction; therefore, the data of the two trials were combined for analysis. The extracellular laccase production by $F$. solani $\mathrm{f}$. sp. glycines was comparable with that of $P$. tulipifera and $S$. commune at 7 and 14 days on MXB medium (Table 2). The extracellular laccase activity markedly increased in F. solani $\mathrm{f}$. sp. glycines samples after this time but there was no increase in laccase activity in the two other fungi (Table 2). The extracellular laccase activity in $F$. solani f. sp. glycines samples did not increase as much when grown on PDB medium and was similar to $S$. commune, which both were higher than $P$. tulipifera,

Table 2. Extracellular laccase and lignin peroxidase activities of three fungal species grown on two different media sampled at 7,14 , and 21 days

\begin{tabular}{|c|c|c|c|c|c|c|}
\hline \multirow[b]{3}{*}{ Enzyme, fungal species } & \multicolumn{6}{|c|}{ Enzyme activity ( $\mu \mathrm{katal} /$ liter) across days ${ }^{z}$} \\
\hline & \multicolumn{2}{|c|}{7} & \multicolumn{2}{|c|}{14} & \multicolumn{2}{|c|}{21} \\
\hline & MXB & PDB & MXB & PDB & MXB & PDB \\
\hline \multicolumn{7}{|l|}{ Laccase } \\
\hline Fusarium solani f. sp. glycines & $34 \mathrm{ab}$ & $14 \mathrm{a}$ & 34 & $13 \mathrm{a}$ & $2,325 \mathrm{a}$ & $11 \mathrm{a}$ \\
\hline Polyporus tulipifera & $26 \mathrm{~b}$ & $0 \mathrm{~b}$ & 17 & $0 \mathrm{~b}$ & $14 \mathrm{~b}$ & $0 \mathrm{~b}$ \\
\hline Schizophyllum commune & $40 \mathrm{~b}$ & $9 \mathrm{a}$ & 4 & $4 \mathrm{~b}$ & $2 \mathrm{~b}$ & $10 \mathrm{a}$ \\
\hline \multicolumn{7}{|l|}{ Lignin peroxidase } \\
\hline F. solani f. sp. glycines & $182 \mathrm{~b}$ & $6 \mathrm{c}$ & $143 \mathrm{a}$ & $27 \mathrm{c}$ & $99 \mathrm{a}$ & $107 \mathrm{~b}$ \\
\hline P. tulipifera & $474 \mathrm{a}$ & $41 \mathrm{~b}$ & $13 \mathrm{~b}$ & $138 \mathrm{a}$ & $3 \mathrm{~b}$ & $253 \mathrm{a}$ \\
\hline S. commune & $48 \mathrm{c}$ & $90 \mathrm{a}$ & $7 \mathrm{~b}$ & $68 \mathrm{~b}$ & $0 \mathrm{~b}$ & $77 \mathrm{~b}$ \\
\hline
\end{tabular}

${ }^{2}$ Mean values are from three to five samples per three and two replications in run one and two, respectively. Numbers followed by different letters in the same column are significantly $(P=0.05)$ different from each other within each enzyme assay. MXB medium (Murashige-Skoog [31] basal salts, B5 [13] vitamins, and $2 \%$ sucrose [pH 5.7]) and PDB = potato dextrose broth.

Table 1. Decolorization of the polymeric dyes, Poly R-478 (PR) and Remazol Brilliant Blue R (RBBR) by Fusarium solani f. sp. glycines, Polyporus tulipifera, and Schizophyllum commune in a liquid medium on a shaker over a 42-day period in two trials for each dye ${ }^{\mathrm{y}}$

\begin{tabular}{|c|c|c|c|c|c|c|c|}
\hline \multirow[b]{2}{*}{ Dye, trial } & \multirow[b]{2}{*}{ Fungal species $^{\mathrm{z}}$} & \multicolumn{6}{|c|}{ Days } \\
\hline & & 1 & 3 & 7 & 14 & 21 & 42 \\
\hline \multicolumn{8}{|l|}{$\mathrm{PR}$} \\
\hline \multirow[t]{4}{*}{1} & Control & $1.16 \mathrm{a}$ & $1.16 \mathrm{a}$ & $1.15 \mathrm{a}$ & $1.14 \mathrm{a}$ & $1.13 \mathrm{a}$ & $1.14 \mathrm{a}$ \\
\hline & F. solani f. sp. glycines & $1.15 \mathrm{~b}$ & $1.14 \mathrm{~b}$ & $0.95 \mathrm{~b}$ & $0.62 \mathrm{~b}$ & $0.61 \mathrm{~b}$ & $0.60 \mathrm{~b}$ \\
\hline & P. tulipifera & $1.15 \mathrm{~b}$ & $1.14 \mathrm{~b}$ & $1.13 \mathrm{a}$ & $1.07 \mathrm{a}$ & $0.99 \mathrm{a}$ & $1.00 \mathrm{a}$ \\
\hline & S. commune & $1.14 \mathrm{~b}$ & $1.15 \mathrm{~b}$ & $1.13 \mathrm{a}$ & $1.10 \mathrm{a}$ & $1.08 \mathrm{a}$ & $0.93 \mathrm{a}$ \\
\hline \multirow[t]{4}{*}{2} & Control & 0.95 & 0.95 & 1.01 & 0.94 & $0.95 \mathrm{a}$ & $1.08 \mathrm{a}$ \\
\hline & F. solani f. sp. glycines & 0.96 & 0.96 & 0.86 & 0.84 & $0.83 \mathrm{ab}$ & $0.84 \mathrm{ab}$ \\
\hline & P. tulipifera & 0.95 & 0.95 & 0.93 & 0.81 & $0.62 \mathrm{~b}$ & $0.54 \mathrm{c}$ \\
\hline & S. commune & 1.00 & 0.97 & 0.90 & 0.87 & $0.78 \mathrm{ab}$ & $0.70 \mathrm{bc}$ \\
\hline \multicolumn{8}{|l|}{ RBBR } \\
\hline \multirow[t]{4}{*}{1} & Control & 4.0 & $3.9 \mathrm{a}$ & $3.9 \mathrm{a}$ & $3.8 \mathrm{a}$ & $3.8 \mathrm{a}$ & $3.7 \mathrm{a}$ \\
\hline & F. solani f. sp. glycines & 3.8 & $3.7 \mathrm{a}$ & $2.9 \mathrm{~b}$ & $1.6 \mathrm{c}$ & $1.3 \mathrm{c}$ & $0.4 \mathrm{c}$ \\
\hline & P. tulipifera & 3.9 & $2.9 \mathrm{~b}$ & $1.7 \mathrm{c}$ & $0.4 \mathrm{~d}$ & $0.4 \mathrm{~d}$ & $0.2 \mathrm{c}$ \\
\hline & S. commune & 4.0 & $3.9 \mathrm{a}$ & $3.6 \mathrm{ab}$ & $2.8 \mathrm{~b}$ & $2.9 \mathrm{~b}$ & $1.9 \mathrm{~b}$ \\
\hline \multirow[t]{4}{*}{2} & Control & 3.6 & 3.6 & $3.5 \mathrm{a}$ & $3.6 \mathrm{a}$ & $3.5 \mathrm{a}$ & $3.6 \mathrm{a}$ \\
\hline & F. solani f. sp. glycines & 3.5 & 3.5 & $1.7 \mathrm{c}$ & $1.6 \mathrm{c}$ & $1.4 \mathrm{c}$ & $1.4 \mathrm{c}$ \\
\hline & P. tulipifera & 3.6 & 3.3 & $3.2 \mathrm{~b}$ & $0.4 \mathrm{~d}$ & $0.3 \mathrm{~d}$ & $0.2 \mathrm{~d}$ \\
\hline & S. commune & 3.6 & 3.6 & $3.5 \mathrm{a}$ & $2.1 \mathrm{~b}$ & $2.4 \mathrm{~b}$ & $2.3 \mathrm{~b}$ \\
\hline
\end{tabular}

${ }^{y}$ Means are based on three replications. Numbers followed by a different letter are significantly $(P=0.05)$ different from each other within a dye and trial.

${ }^{\mathrm{z}}$ The control contained sodium azide. 
for which there was no detectable laccase activity.

Extracellular lignin peroxidase was greatest on MXB medium at day 7 after subculture, then decreased over time (Table 2). $P$. tulipifera had the highest lignin peroxidase activity on day 7 . S. commune had no detectable enzyme activity by day 21. Lignin peroxidase activity tended to increase over time when the three fungal strains were grown on PDB medium, with the greatest activity being detected 21 days after subculture in P. tulipifera (Table 2).

Lignin accumulation and synthesis in soybean hairy roots. There was not a significant trial-treatment interaction; therefore, the data of the two trials were combined for analysis. Thioglycolic acid lignin content was higher in the cell walls of noninoculated PI567374 roots than in noninoculated Spencer roots at the root developmental stage used (about 3 weeks after subculture; Table 3). Roots turned brown $96 \mathrm{~h}$ after inoculation with macroconidial suspensions of $F$. solani $\mathrm{f}$. sp. glycines. Thioglycolic acid lignin concentration was lower in the cell walls of infected roots of both entries than in the controls (Table 3 ).

Following a 96-h infection period, there was an increase in lignin synthesis rate as measured by ${ }^{14} \mathrm{C}$ incorporation into lignin after a 2-h exposure to $\left[{ }^{14} \mathrm{C}\right]$ phenylalanine in hairy roots of both genotypes tested (Table 3). The ${ }^{14} \mathrm{C}$ incorporation into thioglycolic acid lignin of control roots of both genotypes increased about proportionally when samples were compared 2 and $24 \mathrm{~h}$ after exposure to $\left[{ }^{14} \mathrm{C}\right]$ phenylalanine, as one might expect, because lignin should not be degraded in plants. However, a much lower increase in lignin radioactivity occurred in infected roots than in control roots after 24 $\mathrm{h}$ of exposure to $\left[{ }^{14} \mathrm{C}\right]$ phenylalanine, and this was less in Spencer than in PI567374, in comparison with the $2-\mathrm{h}\left[{ }^{14} \mathrm{C}\right]$ phenylalanine exposure (Table 3 ). Lower radioactivity levels were detected in diseased hairy root tissues compared with control tissues $24 \mathrm{~h}$ after $\left[{ }^{14} \mathrm{C}\right]$ phenylalanine exposure in spite of the F. solani $\mathrm{f}$. sp. glycinesinduced activation of ${ }^{14} \mathrm{C}$ incorporation into lignin after $2 \mathrm{~h}$ of exposure to $\left[{ }^{14} \mathrm{C}\right]$ phenylalanine.

\section{DISCUSSION}

Most soilborne fungi are considered to be cellulose degraders only; however, the wood-rotting fungi, such as white-rot basidiomycetes and ascomycetes, have been recognized as the most efficient decomposers of lignin $(28,39)$. Even though investigators have given far less attention to the lignin-degrading capacity of fungi other than the white-rot basidiomycetes fungi, there have been only a few reports describing other potential lignin degraders. It has been shown that $F$. solani was one of the most powerful lignin degraders among 82 microbial strains isolated from forest soils and tested for ligninolytic capacity (35). There was no specific information in this report about specific characteristics of this $F$. solani strain. It also was shown that isolates of Fusarium spp. were capable of extensive degradation of synthetic lignin and were able to use lignin as a sole source of carbon (19). It is known that the different Fusarium spp. and the strains found in both agricultural and native communities can behave very differently (23). Our results show for the first time that $F$. solani $\mathrm{f}$. sp. glycines isolated from soybean plants with SDS (36) were efficient at lignin degradation.

The capability of $F$. solani $\mathrm{f}$. sp. glycines to degrade lignin was demonstrated in our experiments using polymeric dye substrates. Ligninolytic activity of microorganisms is not very substrate specific $(4,14)$, but a good correlation was reported between the efficiency of decolorization of various anthrone-type dyes (including those used in the present study) and lignin degradation by lignin-decomposing fungi (33). The fungal decolorizing ability reflects the ability to decompose lignin and is being used as an important tool for screening fungi for lignin biodegradation. Streptomyces spp., capable of degrading lignin, decolorized the Remazol Brilliant Blue R substrate more efficiently than Poly R-478 (33), which is similar to the results we found with $F$. solani $\mathrm{f}$. sp. glycines and these two dyes. Clearly, the comparison of $F$. solani f. sp. glycines and the two other fungi, known to be active lignin degraders, indicates that $F$. solani f. sp. glycines has a high and comparable power to decolorize

Table 3. Thioglycolic acid lignin content and radioactivity of soybean hairy roots produced from partially resistant line PI567.374 and susceptible cv. Spencer, then inoculated with Fusarium solani f. sp. glycines (FSG) or not inoculated (control), incubated for $96 \mathrm{~h}$, and placed in liquid medium with $\left[{ }^{14} \mathrm{C}\right]$ phenylalanine (Phe) for 2 or $24 \mathrm{~h}$ before lignin isolation and analysis ${ }^{\mathrm{z}}$

\begin{tabular}{|c|c|c|c|c|}
\hline \multirow[b]{2}{*}{ Treatment } & \multicolumn{2}{|c|}{$\begin{array}{l}\text { Lignin content ( } \mu \mathrm{g} \text { per } 10 \mathrm{mg} \\
\text { of alcohol-insoluble residue) }\end{array}$} & \multicolumn{2}{|c|}{$\begin{array}{c}\text { Lignin radioactivity } \\
\text { (percentage of control at } 2 \mathrm{~h} \text { ) }\end{array}$} \\
\hline & $2 \mathrm{~h}\left[{ }^{14} \mathrm{C}\right] \mathrm{Phe}$ & $24 \mathrm{~h}\left[{ }^{14} \mathrm{C}\right]$ Phe & $2 \mathrm{~h}\left[{ }^{14} \mathrm{C}\right] \mathrm{Phe}$ & 24 h $\left[{ }^{14} \mathrm{C}\right] \mathrm{Phe}$ \\
\hline PI567374 control & $238 \mathrm{a}$ & $230 \mathrm{a}$ & $95 \mathrm{c}$ & $938 \mathrm{~b}$ \\
\hline PI567374 + FSG & $144 \mathrm{~b}$ & $135 \mathrm{c}$ & $126 \mathrm{~b}$ & $290 \mathrm{c}$ \\
\hline Spencer control & $152 \mathrm{~b}$ & $194 \mathrm{~b}$ & $95 \mathrm{c}$ & $1,129 \mathrm{a}$ \\
\hline Spencer + FSG & $126 \mathrm{c}$ & $127 \mathrm{c}$ & $150 \mathrm{a}$ & $273 c$ \\
\hline
\end{tabular}

${ }^{\mathrm{z}}$ Mean values are from three to five samples per three and two replications in trial one and two, respectively. Numbers followed by different letters in the same column are significantly $(P=0.05)$ different from each. the dyes tested, especially the Remazol Brilliant Blue R substrate.

Another method that was used to show that $F$. solani f. sp. glycines could degrade lignin was to measure the ${ }^{14} \mathrm{CO}_{2}$ evolved after incubation of $F$. solani f. sp. glycines with $\left[{ }^{14} \mathrm{C}\right]$-labeled Klason lignin. Klason lignin is known to be contaminated with protein if obtained as an insoluble residue after dissolution of other cell wall constituents in $72 \%$ sulfuric acid only, unless the protein components are removed by hydrolysis in hot diluted acid (12). We used both $72 \%\left(20^{\circ} \mathrm{C}\right)$ and $3 \%$ (boiling) sulfuric acid treatments to obtain Klason lignin for the degradation tests, a treatment that should remove any protein.

Most ligninolytic fungi require a high level of easily metabolized co-substrates to decompose lignin (20). However, $F$. solani mycelia did not require any additional carbon source when grown on wheat straw, where they degraded cell wall polysaccharides and lignin simultaneously ( 30.4 and $25 \%$ of the total present, respectively; 35). We found that decomposition of radioactive Klason lignin occurred on unsupplemented water-agar medium in the absence of other substrates. However, additional tests are needed to determine how culture conditions affect the lignin-degrading activity of $F$. solani f. sp. glycines because it is known that factors such as aeration, nitrogen, sulfur, carbon availability, and the nature of aromatic compounds can dramatically affect the lignin-degrading enzyme production by fungi $(7,38,40)$.

Finally, we measured the major fungal lignin-degrading enzymes (laccase and lignin peroxidase) in the culture medium of $F$. solani f. sp. glycines and demonstrated that $F$. solani f. sp. glycines has these enzymatic activities at levels similar to or even exceeding that of the other lignin-degrading fungi. In our experiments, the lowest laccase and lignin peroxidase activities and aromatic dye decolorizations were found with the $S$. commune samples. It was reported earlier that, even though $S$. commune was capable of demethylating lignin and releasing $\mathrm{CO}_{2}$ as a result of lignin modification, no laccase or lignin peroxidase or Poly B-411-degrading activities were detected in this fungal culture (41).

The partially resistant PI567374 had a higher lignin concentration in the hairy root cell walls, a result similar to that found in our studies on the lignin content of whole soybean plant roots of the same entries (26). The cell wall is a major physical barrier against pathogen invasion; therefore, the higher lignin concentration in the root cell walls of the partially resistant PI567374 could provide a more effective barrier to fungal penetration. This possibility needs to be tested with a larger number of cultivars and lines varying in SDS susceptibility before a conclusion can 
be made. The lignin component is especially important because it usually is resistant to degradation by most microorganisms $(21,34,42)$ because the various linkages between the aromatic monomeric units are difficult to hydrolyze (3).

Inoculation of hairy roots with $F$. solani f. sp. glycines increased the incorporation of $\left[{ }^{14} \mathrm{C}\right]$-label into lignin in $2 \mathrm{~h}$ (Table 2), a response commonly associated with fungal attack or elicitor effects $(1,42)$. However, the amount of radioactivity was lower in diseased tissues compared with controls after a 24-h incubation with $\left[{ }^{14} \mathrm{C}\right]$ phenylalanine. The lignin content also was decreased in the $F$. solani f. sp. glycinesinoculated roots. Lignin is known to be a final product of the phenylpropanoid pathway that is not degraded by plant enzymatic systems; therefore, these results indicate that $F$. solani f. sp. glycines is a potential degrader of lignin and lignin-like materials. It should be noted that the rate of lignin degradation could be underestimated in studies where the labeling approach is applied because the monomeric products released as a result of lignin decomposition might be reused in lignin synthesis.

These results indicate for the first time that $F$. solani f. sp. glycines can degrade lignin in soybean roots during infection, a capability that might enhance root colonization and SDS development. Because lignin can provide a nondegradable barrier for most microorganisms, the lignin level and composition could be of importance for plant resistance $(21,34,42)$, and modification of root lignin composition and concentration might be a means for increasing SDS resistance. It was reported that uncondensed lignin was more susceptible than condensed lignin to degradation by white-rot fungi in wheat straw (2).

Understanding the biochemical basis of plant resistance to fungal infection may provide the foundation for using genetic engineering to develop resistant plants. Results obtained in this study indicate that modification of phenolic metabolism aimed at enhancing lignin level and also decreasing lignin degradability in soybean roots may help to reduce root infection and, thus, to combat soilborne pathogens such as $F$. solani f. sp. glycines.

\section{ACKNOWLEDGMENTS}

This study was supported partly by funds from Illinois Soybean Program Operating Board, the Soybean Disease Biotechnology Center, the United Soybean Board, the NATO Collaborative Research Program (ref. LST.CLG.976259 and JSTC.CLG. 978212), the Illinois Agricultural Experiment Station, and the United States Department of Agriculture-Agricultural Research Service.

\section{LITERATURE CITED}

1. Bruce, R. J., and West, C. A. 1989. Elicitation of lignin biosynthesis and isoperoxidase activity by pectic fragments in suspension cultures of castor bean. Plant Physiol. 91:889-897.

2. Burlat, V., Ambert, K., Ruel, K., and Joseleau, J.-P. 1997. Relationship between the nature of lignin and the morphology of degradation performed by white-rot fungi. Plant Physiol. Biochem. 35:645-654.

3. Chang, H.-M., Chen, C.-L., and Kirk, T. K. 1980. The chemistry of lignin degradation by white-rot fungi. Pages 215-230 in: Lignin Biodegradation: Microbiology, Chemistry, and Applications, Volume I. T. K. Kirk, T. Higuchi, and H.-M. Chang, eds. CRC Press, Boca Raton, FL.

4. Chet, J., Trojanowski, J., and Huettermann, A. 1985. Decolourization of the dye poly B-411 and its correlation with lignin degradation by fungi. Microbios Lett. 29:37-41.

5. Cho, H.-J., Farrand, S. K., Noel, G. R., and Widholm, J. M. 2000. High-efficiency induction of soybean hairy roots and propagation of the soybean cyst nematode. Planta 210:195204.

6. Dixon, R. A., Achnine, L., Kota, P., Liu, P.-K., Reddy, M. S. S., and Wang, L. 2002. The phenylpropanoid pathway and plant defencea genomic perspective. Mol. Plant Biol. 3:371390.

7. D’Souza, T. M., Merritt, C. S., and Reddy, C. A. 1999. Lignin-modifying enzymes of the white rot basidiomycete Ganoderma lucidum. Appl. Environ. Microbiol. 65:5307-5313.

8. Effland, M. J. 1977. Modified procedure to determine acid-insoluble lignin in wood and pulp. Tappi 60E:143-144.

9. Eggert, C., Temp, U., Dean, J. F. D., and Eriksson, K.-E. L. 1996. A fungal metabolite mediates degradation of non-phenolic lignin structures and synthetic lignin by laccase. FEBS Lett. 391:144-148.

10. Elfstrand, M., Sitbon, F., Lapierre, C., Bottin, A., and von Arnold, S. 2002. Altered lignin structure and resistance to pathogens in spi 2expressing tobacco plants. Planta 214:708-716.

11. Friend, J. 1976. Lignification in infected tissues. Pages 291-303 in: Biochem Aspects of Plant-Parasite Relationships, J. Friend and D. R. Threfall, eds. Academic Press, London: New York.

12. Fry, S. C. 1988. The Growing Plant Cell Wall: Chemical and Metabolic Analysis. Longman Scientific \& Technical, Harlow, Essex, UK.

13. Gamborg, O. L., Miller, R. A., and Ojima, K. 1968. Nutrient requirements of suspension cultures of soybean root cells. Exp. Cell Res. 50:151-158.

14. Glenn, J. K., and Gold, M. H. 1983. Decolorization of several polymeric dyes by the lignin degrading basidiomycete Phanerochaete chrysosporium. Appl. Environ. Microbiol. 45:17411747.

15. Hartman, G. L., Huang, Y. H., Nelson, R. L., and Noel, G. R. 1997. Germplasm evaluation of Glycine max for resistance to Fusarium solani, the causal organism of sudden death syndrome. Plant Dis. 81:515-518.

16. Hartman, G. L., Sinclair, J. B., and Rupe, J. C. 1999. Compendium of Soybean Diseases, 4th ed. American Phytopathological Society, St. Paul, MN.

17. Huang, Y. H., and Hartman, G. L. 1998. Reaction of selected soybean genotypes to isolates of Fusarium solani f. sp. glycines and their culture filtrates. Plant Dis. 82:999-1002.

18. Iqbal, M. J., Yaegashi, S., Njiti, V. N., Ahsan, R., Cryder, K. L., and Lightfoot, D. A. 2002. Resistance locus pyramids alter transcript abundance in soybean roots inoculated with Fusarium solani f. sp. glycines. Mol. Gen. Genet. 268:407-417.

19. Iwahara, S. 1980. Microbial degradation of DHP. Pages 215-230 in: Lignin Biodegradation: Microbiology, Chemistry, and Applications, Volume I. T. K. Kirk, T. Higuchi, and H.M. Chang, eds. CRC Press, Boca Raton, FL.

20. Kirk, T. K., Schultz, S., Connors, W. J., Lorenz, L. F., and Zeikus, J. G. 1978. Influence of culture parameters on lignin metabolism by
Phanerochaete chrysosporium. Arch. Microbiol. 117:277-285.

21. Lange, B. M., Lapierre, C., and Sandermann, H. J. 1995. Elicitor-induced spruce stress ligninStructural similarity to early developmental lignins. Plant Physiol. 108:1277-1287.

22. Leonowicz, A., Sckalarz, G., and WoitasWasilewska, M. 1985. The effect of fungal laccase on fractionated lignizylphozates. Phytochemistry 24:393-396.

23. Leslie, J. F., Zeller, K. A., and Summerell, B. A. 2001. Icebergs in populations of Fusarium. Physiol. Mol. Plant Pathol. 59:107-117.

24. Lewis, N., and Yamamoto, E. 1990. Lignin: occurrence, biogenesis and biodegradation. Annu. Rev. Plant Physiol. Plant Mol. Biol. 41:455-496.

25. Li, S., Lygin, A., Zernova, O., Lozovaya, V., Hartman, G., and Widholm, J. 2002. Response of hairy roots of different soybean genotypes to Fusarium solani f. sp. glycines. (Abstr.) Phytopathology 92:S47.

26. Lozovaya, V. V., Lygin, A. V., Li, S., Hartman, G. L., and Widholm, J. M. 2004. Biochemical response of soybean roots to Fusarium solani f. sp. glycines infection. Crop Sci. 44:819-826.

27. Lozovaya, V. V., Lygin, A. V., Zernova, O., Li, S., Hartman, G. L., and Widholm, J. M. 2004 Isoflavonoid accumulation in soybean hairy roots upon treatment with Fusarium solani. Plant Physiol. Biochem. 42:671-679.

28. Martin, J. P., and Haider, K. 1971. Microbial activity in relation to soil humus formation. Soil Sci. 111:54-63.

29. Minussi, R. C., de Moraes, S. G., Pastore, G. M., and Duran, N. 2001. Biodegradation screening of synthetic dyes by four white-rot fungi in a solid medium: possible role of sidephores. Lett. Appl. Microbiol. 33:21-28.

30. Munoz, C., Guillen, F., Martinez, A. T., and Martinez, M. J. 1997. Laccase isoenzimes of Pleurotus eryngii: catalytic properties, and participation in activation of molecular oxygen and $\mathrm{Mn} 2+$ oxidation. Appl. Environ. Microbiol. 53:2166-2174

31. Murashige, T., and Skoog, F. 1962. A revised medium for rapid growth and bioassays with tobacco tissue cultures. Physiol. Plant. 15:473497.

32. Otsuka, Y., Sonoki, T., Ikeda, S., Kajita, S., and Nakamura, M. 2003. Detection and characterization on novel extracellular fungal enzyme that catalyzes the specific and hydrolytic cleavage of lignin guaiacylglycerol beta-aryl ether linkage. Eur. J. Biochem. 270:23532362.

33. Pasti, M. B., and Crawford, D. L. 1991. Relationships between the abilities of streptomycetes to decolorize three anthrone-type dyes and to degrade lignocellulose. Can. J. Microbiol. 37:902-907.

34. Ride, J. P. 1983. Structural barriers in defense. Pages 215-216 in: Biochemical Plant Pathology, J. A. Callow, ed. John Wiley and Sons, Chichester, UK.

35. Rodriguez, A., Perestelo, F., Carnicero, A., Regalado, V., Perez, R., De la Fuente, G., and Falcon, M. A. 1996. Degradation of natural lignins and lignocellulosic substrates by soilinhabiting fungi imperfecti. FEMS Microbiol. Ecol. 21:213-219.

36. Rupe, J. C. 1989. Frequency and pathogenicity of Fusarium solani recovered from soybeans with sudden death syndrome. Plant Dis. 73:581-584.

37. Savka, M. A., Ravillion, B., Noel, G. R., and Farrand, S. K. 1990. Induction of hairy roots on cultivated soybean genotypes and their use to propagate the soybean cyst nematode. Phytopathology 80:502-508.

38. Sethuraman, A., Akin, D. E., and Eriksson, K.E. L. 1999. Production of ligninolytic enzymes and synthetic lignin mineralization by the bird's nest fungus Cyathus stercoreus. Appl. 
Microbiol. Biotechnol. 52:689-697.

39. Stolp, H. 1988. Microbial Ecology: Organisms, Habitats, Activities. Cambridge University Press, Cambridge.

40. Tekere, M., Mswaka, A. Y., Zvauya, R., and Read, J. S. 2001. Growth, dye degradation and ligninolytic activity studies on Zimbabwean white rot fungi. Enzyme Microb. Technol. 28:420-426.

41. Trojanowski, J., De Vries, O. M. H., Wessels, J. G. H., and Huettermann, A. 1986. Capacity to demethylate lignin and oxidase production by Schizophyllum commune (monokaryon) and Polyporus species. Microbios Lett. 33:67-70.

42. Vance, C. P., Kirk, T. K., and Sherwood, R. T. 1980. Lignification as a mechanism of disease resistance. Annu. Rev. Phytopathol. 18:259288. 